\title{
Analyses of Yield and Economic Response from Foliar Fungicide and Insecticide Applications to Soybean in the North Central United States
}

Yuba R. Kandel and Daren S. Mueller, Department of Plant Pathology and Microbiology, Chad E. Hart, Department of Economics, and Nathan R. C. Bestor, Department of Plant Pathology and Microbiology, lowa State University, Ames 50011; Carl A. Bradley, Department of Plant Pathology, University of Kentucky, Princeton 42445; Keith A. Ames, Department of Crop Sciences, University of Illinois, Urbana 61801; Loren J. Giesler, Department of Plant Pathology, University of Nebraska-Lincoln 68508; and Kiersten A. Wise, Department of Botany and Plant Pathology, Purdue University, West Lafayette, IN 47907

Accepted for publication 22 September 2016.

\section{ABSTRACT}

Foliar disease and insect management on soybean (Glycine max L. Merrill) in the North Central region of the United States has been increasingly accomplished through foliar fungicide and insecticide application. Data from research trials conducted in Illinois, Indiana, lowa, and Nebraska were compiled from 2008 to 2014 to determine the impact of fungicide, insecticide, and fungicide + insecticide applications on soybean yield and profitability. In each state, field experiments occurred each year in two to seven locations. All treatments were applied at the R3 growth stage. Disease and insect pressure were very low in all states and years. A foliar application of fungicide, insecticide, or the combination, increased yield in seven out of 14 total site-years $(P<0.10)$. Economic analysis using an average soybean price of $\$ 0.42$ per kilogram and average application cost of $\$ 62$ per hectare indicated that fungicide applications were only profitable in $14 \%$ of the trial site-years. Insecticide alone and fungicide + insecticide was profitable in $39 \%$ and $45 \%$ of site-years, respectively. Effect of fungicide class on yield was inconsistent. Our results indicate that although yield increases can occur with foliar fungicide and/or insecticide treatments, current market prices and application costs may limit profitability when disease and/or insect pressure is low.

\section{INTRODUCTION}

Soybean (Glycine max L. Merrill) is an important commodity in the United States, and is planted on 32 million hectares on average annually from 2011 to 2015 , with a value between $\$ 34$ and $\$ 44$ billion (USDA-NASS, National Statistics for Soybeans). In the North Central region, there are few foliar fungal diseases that annually limit yield. Of these diseases, Septoria brown spot, caused by Septoria glycines Hemmi, and frogeye leaf spot, caused by Cercospora sojina Hara, are the most common (Cruz et al. 2010; Dorrance et al. 2010; Hartman, 2015; Wise and Newman 2015). Traditionally, farmers have relied on cultivar resistance and cultural practices, such as tillage and crop rotation, to manage these diseases when necessary. Foliar fungicides are available to manage these diseases; however, fungicides are not needed annually for soybean disease control in the North Central region since foliar disease levels are low most years.

Although foliar disease severity can be inconsistent in the North Central region, fungicide use in soybean has increased dramatically since 2005 (Mueller et al. 2013). This increase in fungicide use occurred for several reasons, including an increase in awareness of soybean diseases and more foliar fungicides becoming available for use on soybean. Also, some fungicides are promoted for their physiological benefits that may increase soy-

Corresponding author: Kiersten Wise. Email: kawise@purdue.edu.

bean yield, even in the absence of disease (Mahoney et al. 2015; Wise and Mueller 2011).

Foliar fungicides used on soybean are primarily the quinoneoutside inhibiting (QoI) class of fungicides (Fungicide Resistance Action Committee [FRAC] group 11) and act by binding at complex III in the mitochondrial respiration pathway (Bartlett et al. 2002). Other common foliar fungicides on soybean belong to the sterol biosynthesis inhibiting demethylation inhibiting fungicides (FRAC group 3) and are in the demethylation inhibitor (DMI) class, inhibiting ergosterol production by the fungus (FRAC 2016). More recently, succinate dehydrogenase inhibiting (SDHI; FRAC group 7) fungicides were labeled for use on soybean. These fungicides are classified as respiration inhibitors similar to QoI fungicides; however, they bind at complex II in the mitochondrial respiration pathway rather than at complex III (FRAC 2016). All of these fungicide groups are considered to have broad-spectrum activity on foliar fungal soybean diseases, and are labeled for control of Septoria brown spot and frogeye leaf spot (Wise 2016).

Insecticide use on soybean also has dramatically increased since the discovery of soybean aphid (Aphid glycines Matsumura) in the North Central region (Hartman et al. 2001; Ragsdale et al. 2011). Outbreaks of soybean aphid populations in the North Central region in 2003 and 2005 necessitated insecticide use in soybean (O'Neal 2005), and preventative applications continue to protect the crop from perceived insect threats. Farmers aim to minimize the number of applications in soybean since equipment tracks across emerged soybeans can cause a reduction in yield (Hanna et al. 2007) and multiple applications result in increased fuel, labor, and application costs. Therefore, farmers may com- 
bine pesticides such as fungicides and insecticides to minimize the number of applications that occur in soybean.

In the last six years, U.S. soybean prices varied significantly, from a low of $\$ 0.35 / \mathrm{kg}$ for the 2009 crop to a high of $\$ 0.53 / \mathrm{kg}$ for the drought-stricken 2012 crop (USDA-NASS, National Statistics for Soybeans). On average from 2009 to 2014, the soybean price was $\$ 0.42 / \mathrm{kg}$. In times of fluctuating prices and market uncertainty, farmers need to minimize input costs to increase profitability. Understanding when and where fungicide and insecticide applications may increase yield and profitability is important in helping farmers make choices on including these inputs in their production systems. To better understand the impact of fungicide, insecticide, and combination applications on soybean yield and profitability, data from trials conducted between 2008 and 2014 were analyzed across four North Central states: Illinois, Indiana, Iowa, and Nebraska. The economic returns for each application scenario were also calculated to determine when and where these applications might be profitable for soybean farmers.

\section{EVALUATION OF FUNGICIDES AND INSECTICIDES ACROSS NORTH CENTRAL STATES}

Our main goal was to examine overall effect of fungicide and insecticide on soybean yield across states rather than to compare individual products; therefore, treatments from all states were placed into three groups: (i) fungicide alone; (ii) fungicide + insecticide; and (iii) insecticide alone. Fungicides were further grouped based on chemical class: (i) QoI; (ii) DMI; (iii) DMI + QoI; and (iv) SDHI + QoI to determine effect of fungicide class or combination of classes on yield and profitability. In all trials, foliar diseases were the primary diseases of importance and no other yield-limiting diseases were observed. Since the products for fungicides and insecticides differed across states and years, data from each state-year were analyzed and presented separately.

Illinois. Field research trials were conducted at six locations in Illinois in 2009 and 2010. Four of the locations each year were conducted at University of Illinois research farms, which were the Crop Sciences Research and Education Center near Urbana, the Northern Illinois Agronomy Research Center near DeKalb, the Northwestern Illinois Agricultural Research and Demonstration Center near Monmouth, and the Orr Agricultural Research and Demonstration Center near Perry. The other two locations were the Southern Illinois University Belleville Research Center near Belleville and a farmer's field near Ridgway, IL. Corn (Zea mays L.) was the preceding crop at all locations each year, and all fields had a recent corn-soybean or corn-corn-soybean rotation history. Soybean seeds were planted at a population of 346,535 viable seeds/ha. All plots were four rows wide on $38.1 \mathrm{~cm}$ centers and $6.1 \mathrm{~m}$ long. At each location, four regionally adapted soybean cultivars were planted (Table 1). Plots were arranged in a randomized complete block design and replicated three times per location. Treatments were applied at the R3 soybean development stage (Fehr et al. 1971) and consisted of treatments listed in Table 2. A non-treated control also was included at all locations.

At all locations in 2009, and at the Monmouth, DeKalb, and Ridgway locations in 2010, all treatments were applied with a $\mathrm{CO}_{2}$-pressurized tractor-mounted sprayer. The spray boom was 1.5 m wide with TJ60-8003 (Spraying Systems Co., Wheaton, IL) nozzles spaced $50.8 \mathrm{~cm}$ apart. The sprayer was pressurized to 345 $\mathrm{kPa}$. At the Perry, Urbana and Belleville locations in 2010, a $\mathrm{CO}_{2^{-}}$ pressurized backpack sprayer was used with a 1.5 -m-wide spray boom with TJ60-8002 nozzles spaced $50.8 \mathrm{~cm}$ apart. The sprayer was pressurized to $276 \mathrm{kPa}$. A spray volume of 196.8 liter/ha was achieved with both sprayers.

TABLE 1

List of cultivars planted Illinois, Indiana, lowa, and Nebraska during 2008 to 2014 in a study designed to examine the effect of fungicide and insecticide on soybean yield.

State

Illinois Year 2009

Cultivars

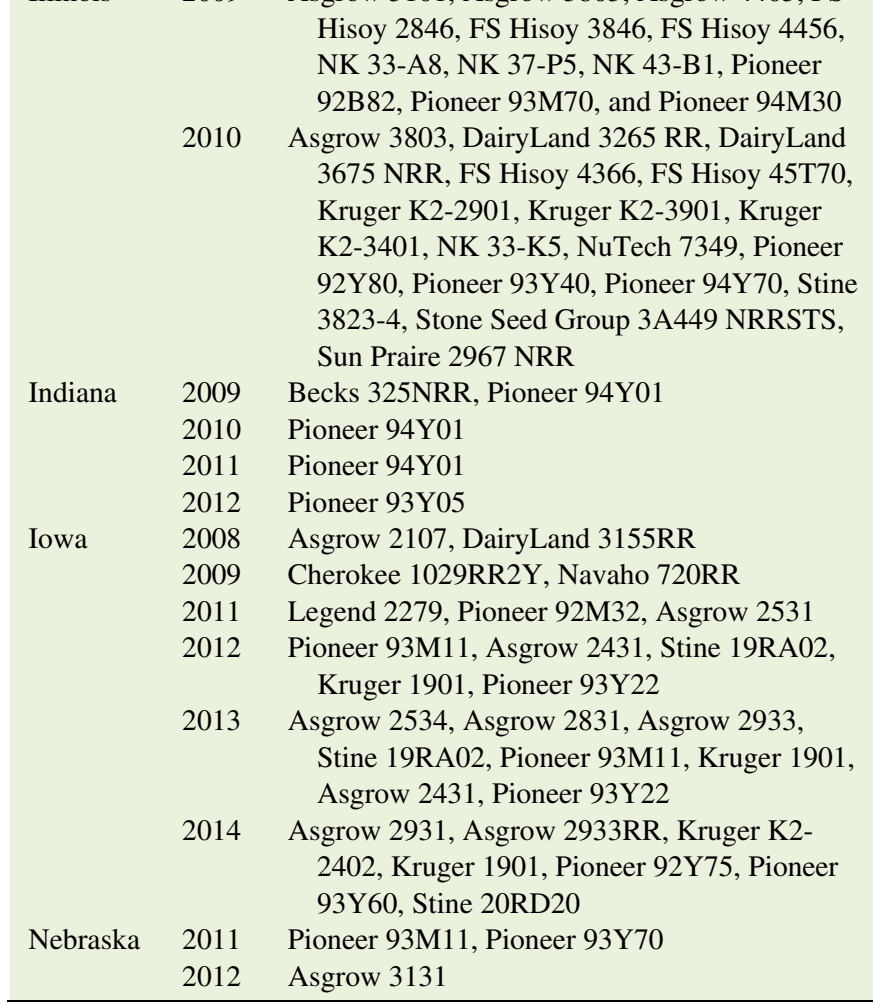

Foliar diseases and insects were assessed visually approximately three weeks after treatments were applied. Disease ratings were reported as the percent disease severity in the upper canopy of rated plants. Plots were harvested with a small-plot combine, and grain yields were standardized to $13 \%$ seed moisture. Data were analyzed using SAS version 9.3 (SAS Institute Inc., Cary, NC). Cultivars were combined for analysis. Analysis of variance was performed using PROC GLIMMIX considering treatment group as a fixed effect factor and experiment location and replication within the location as a random factor. Means were separated using Fisher's protected LSD at $P=0.10$.

Indiana. Field trials were conducted at Purdue University Agricultural Centers from 2009 to 2012. Trials were conducted at the Davis Purdue Agricultural Center near Farmland in 2012, the Northeast Purdue Agricultural Center near Columbia City in 2011 and 2012, the Pinney Purdue Agricultural Center near Wanatah from 2010 to 2012, the Throckmorton Purdue Agricultural Center in Lafayette from 2009 to 2012, the Southeast Purdue Agricultural Center near Butlerville from 2010 to 2012, and the Southwest Purdue Agricultural Center near Vincennes from 2009 to 2011. Corn was the previous crop at all locations and years, and all fields were in a corn-soybean rotation. Soybean seeds were planted at population between 321,782 seeds/ha and 371,287 seeds/ha at each location. Trials conducted in 2009 consisted of plots that were 11 rows wide, planted on 19.1-cm centers, and $12.2 \mathrm{~m}$ long. Trials conducted in 2010 to 2012 consisted of plots that were eight rows wide, planted on $38.1-\mathrm{cm}$ centers and ranging from 45.8 to $91.5 \mathrm{~m}$ long. Plots were arranged in a randomized complete block design and replicated three to six 
TABLE 2

List of fungicide and insecticide products applied alone or in combination in Illinois, lowa, Indiana, and Nebraska during 2008 to 2014 to examine the effect of foliar application of fungicide and insecticide on soybean yield.

\begin{tabular}{lll} 
State & Year & $\begin{array}{l}\text { Fungicidex alone } \\
\text { (rate in } \mathbf{~ m l} / \mathbf{h a})\end{array}$ \\
\hline Illinois & 2009 & Quadris (439), Stratego YLD (365) \\
& 2010 & Quadris (439), Stratego YLD (365) \\
Indiana & 2009 & $\begin{array}{l}\text { Headline (439), Quadris (439), } \\
\text { Stratego (731) }\end{array}$ \\
& 2010 & $\begin{array}{l}\text { Headline (439) } \\
\text { Headline (439), Stratego YLD (292) }\end{array}$ \\
& 2011 &
\end{tabular}

2012 Headline (439), Stratego YLD (292)

Iowa 2008 Headline (439), Stratego YLD (292)

2009 Aproach (439), Domark (292), Headline (439), Stratego YLD (292)

2011 Domark (365), Priaxor (292), Stratego YLD (292)

2012 Aproach (439), Domark (292), Evito (146), Headline (439), Quadris (439), Stratego YLD (292), Topguard (512)

2013 Aproach (439), Aproach Prima (497), Custodia (629), Domark (292), Fortix (365), Headline (439), Priaxor (292), Quadris Top (804), Quilt Xcel (1096), Stratego YLD (292), Topguard (512)

2014 Aproach (439), Aproach Prima (499), Custodia (629), Equation (439), Fortix (365), Priaxor (292), Priaxor + Domark (292 + 292), Quadris Top (1023), Quilt Xcel (767), Stratego YLD (292), Topguard (365)

Nebraska 2011 Evito (146), Headline (439), Quilt Xcel (1023), Stratego YLD (292)

2012 Evito (146), Headline (439), Priaxor (292), Quilt Xcel (767), Stratego YLD (292), Topguard (512)
Insecticidey alone (rate in $\mathrm{ml} / \mathrm{ha}$ )

Fungicide + Insecticide (rate in $\mathrm{ml} / \mathrm{ha}$ )

Leverage (278), Warrior (234)

Leverage (278), Warrior (234)

Leverage (278), Respect (234), Warrior (187) ... $\ldots$

$\cdots$

Asana XL (702), Leverage (278)

Asana XL (702), Belay (219), Fastac (234), Leverage (278)

Belay 219 Fastac (234)

Fastac (234), Leverage 360 (205)

Skyraider (468)

Asana XL (702), Fastac (278), Leverage 360 (2045), Skyraider (467.7)

Mustang Max (219)

Hero (365) Leverage $(365+278)$ Leverage $(292+278)$ Leverage $(292+278)$
Quadris + Warrior $(439+234)$, Stratego YLD + Leverage $(365+278)$

Quadris + Warrior $(439+234)$, Stratego YLD +

Headline + Respect $(439+234)$, Quadris + Warrior (439 $+187)$, Stratego + Leverage $(731+278)$

Headline + Warrior $(439+234)$

Headline + Warrior $(439+234)$, Stratego YLD +

Headline + Warrior $(439+234)$, Stratego YLD +

Stratego YLD + Leverage $(292+278)$

Aproach + Asana XL $(439+702)$, Domark + Belay $(292+219)$, Headline + Fastac $(439+234)$, Stratego YLD + Leverage $(292+278)$

Domark + Belay $(292+219)$, Priaxor + Fastac $(292+$ 234), Stratego YLD + Leverage $(292+278)$

Aproach+Asana XL $(439+702)$, Headline + Fastac $(439+234)$, Priaxor + Fastac $(292+234)$, Quilt Xcel + Warrior (767 + 110), Stratego YLD + Leverage 360 $(292+205)$, Topguard + Declare $(511+73)$

Aproach + Asana XL $(439+702)$, Custodia + Skyraider $(629+468)$, Priaxor + Fastac $(292+278)$, Stratego YLD + Leverage $360(292+205)$

Aproach + Asana XL $(439+702)$, Custodia + Skyraider $(629+468)$, Priaxor + Fastac $(292+278)$, Stratego YLD + Leverage $360(292+205)$

Evito + Mustang Max $(146+219)$, Headline + Respect $(439+219)$, Quilt Xcel + Warrior II $(1023+73)$, Stratego YLD + Leverage $360(292+205)$

Evito + Hero $(146+365)$, Headline + Respect $(438+$ $219)$, Priaxor + Respect $(292+219)$, Quilt Xcel + Warrior II $(767+73)$, Stratego YLD + Leverage 360 $(292+205)$, Topguard + Declare $(511+73)$

\footnotetext{
x Active ingredients, Fungicide Resistance Action Committee (FRAC) group (http://www.frac.info), and manufacturer/supplier of the fungicides: Aproach (picoxystrobin, 11, DuPont, Wilmington, DE), Aproach Prima (cyproconazole + picoxystrobin, $3+11$, DuPont), Custodia (tebuconazole + azoxystrobin, 3 +11, Adama Australia Pty Ltd, St Leonards, Australia), Domark 230 ME (tetraconazole, 3, Valent U.S.A., Walnut Creek, CA), EquationTM(azoxystrobin, 11, Cheminova Inc., Research Triangle Park, NC), Evito 480 SC (fluoxastrobin, 11, Arysta LifeScience North America LLC, Cary, NC), Fortix (flutriafol + fluoxastrobin, $3+11$, Cheminova Inc.), Headline (pyraclostrobin, 11, BASF Corporation, Research Triangle Park, NC), Priaxor (fluxapyroxad + pyraclostrobin, 7+11, BASF Corporation), Quadris (azoxystrobin, 11, Syngenta Crop Protection LLC, Greensboro, NC), Quadris Top (difenoconazole + azoxystrobin, $3+11$, Syngenta Crop Protection LLC), Quilt Xcel (propiconazole + azoxystrobin, 3+11, Syngenta Crop Protection LLC), Stratego (propiconazole + trifloxystrobin, $3+11$, Bayer CropScience, Research Traingle PK, NC), Stratego YLD (prothioconazole + trifloxystrobin, $3+11$, Bayer CropScience), Topguard (flutriafol, 3, Cheminova Inc.)

y Active ingredients, Insecticide Resistance Action Committee (IRAC) group (http://www.irac-online.org), and manufacturer/supplier of the insecticides: Asana XL (esfenvalerate, 3, DuPont), Belay (clothianidin, 4A, Valent USA Corporation, Walnut Creek, CA), Declare (gammacyhalothrin, 3a, FMC Corporation Agricultural Products Group), Fastac 10 EC (alpha-cypermethrin, 3, BASF Corporation, Florham Park, NJ), Hero (zeta-cypermethrin + bifenthrin, 3a, FMC Corporation Agricultural Products Group), Leverage 2.7 (imidacloprid + beta-cyfluthrin, $3+4 a$, Bayer CropScience), Leverage 360 (imidacloprid + beta-cyfluthrin, $3+4 \mathrm{a}$, Bayer CropScience), Mustang Mix (zeta-cypermethrin, 3, FMC Corporation, Philadelhpia PA), Respect (zeta-cypermethrin, 3, BASF Corporation), SkyraiderTM (bifenthrin + imidaclorid, 3 + 4a, Adama USA, Raleigh, NC), Warrior (lamda-cyhalothrin, 3, Syngenta Crop Protection, LLC), Warrior II (lambda-cyhalothrin, 3, Syngenta Crop Protection, LLC)
} 
times per location. Treatments were applied at the R3 soybean development stage. Treatment combinations are listed in Table 2. In 2009, all treatments were applied using a $\mathrm{CO}_{2}$-pressurized backpack sprayer with 3.1-m-wide spray boom with TJ-VS 8002 nozzles spaced $50.8 \mathrm{~cm}$ apart, which delivered 140.5 liters/ha at $276 \mathrm{kPa}$. In 2010 to 2012, fungicides were applied with a Lee self-propelled sprayer (LeeAgra Inc., Lubbock, TX) equipped with a compressed air system and a 3.1-m-wide boom fitted with six TJ-VS 8002 nozzles spaced $50.8 \mathrm{~cm}$ apart, which delivered 140.5 liters/ha at $276 \mathrm{kPa}$.

Foliar disease was assessed two weeks after treatment application. Disease severity was measured from 10 leaves per plot in 2009 and 30 leaves per plot in 2010 to 2012 from the inner two and four rows of the plot, respectively. Disease severity was measured for each disease present at the time of rating. Severity assessments continued every two weeks until R5 in trials conducted from 2010 to 2012. Insect populations were noted in all trials every two weeks after application. Plots were harvested with a small-plot combine, and grain yields were standardized to $13 \%$ seed moisture. Data were analyzed in SAS using PROC GLIMMIX by dividing treatments in groups as explained above. Fungicide class was not analyzed in Indiana because most fungicides were from one class.

Iowa. Field trials were conducted at five to seven Iowa State University (ISU) research farms each year from 2008 to 2009 and 2011 to 2014 for a total of six years. Trials were conducted at Northwest ISU Research Farm in O'Brien County near Sutherland, Northeastern ISU Research Farm in Floyd County near Nashua, Southeastern ISU Research Farm in Washington County near Crawfordsville for all six years; Northern ISU Research Farm in Hancock County near Kanawha in 2008, 2011to 2014; Curtiss Research Farm in Story County near Ames in 2009, 2011 to 2014; Armstrong Research Farm in Adair County near Lewis 2008, 2011 to 2014; and McNay Memorial Research and Demonstration Farm in Lucas County near Chariton 2012 to 2014. The previous crop was corn for all trials. Soybean seeds were planted at populations between 309,406 to 465,347 seeds/ha. In 2008, each plot was four rows wide on $76.2 \mathrm{~cm}$ centers and $10.7 \mathrm{~m}$ long. From 2009 to 2014, plots were six rows wide on $76.2 \mathrm{~cm}$ spacing and ranged from 10.7 to $15.3 \mathrm{~m}$ long. Soybean cultivars used in this study are listed in Table 1. Plots were arranged in a randomized complete block with five to six replications at each location all years.

Treatments were applied at the R3 soybean development stage to the middle two rows of each plot in 2008 and the middle four rows of each plot in 2009 to 2012. Treatment products and rates are listed in Table 2. In 2008 to 2012, all treatments were applied using a $\mathrm{CO}_{2}$-pressurized backpack sprayer with $3.1 \mathrm{~m}$ wide spray boom with the appropriate nozzles spaced $50.8 \mathrm{~cm}$ apart, which delivered 140.5 liters/ha at $276 \mathrm{kPa}$. In 2013 and 2014, treatments were applied with self-propelled small research plot sprayer consisting of six Teejet 11015 XR flat fan nozzles spaced $50.8 \mathrm{~cm}$ apart and sprayed at a pressure of $276 \mathrm{kPa}$ that delivered 140.5 liters/ha.

Disease ratings were recorded as percent leaf area affected by disease. All fungal foliar diseases controlled by fungicides present were assessed. Other diseases also were noted when observed. Disease severity on 10 leaflets was assessed in each of the upper and lower canopies of every plot. In 2008, disease data were collected from the middle two rows of each plot. In 2009 through 2014 , disease data were collected from the second and fifth rows. Disease severity was assessed during the grain fill period between growth stages R5 and R6. The presence and level of soybean insect pests were recorded during the season. Yield data were collected from the center two rows of each plot using a small-plot combine. Grain weight and grain moisture were recorded for each plot and yields were standardized to $13 \%$ moisture. Data were analyzed using the methods explained previously.

Nebraska. Trials were conducted at four locations in 2011 and 2012. In 2011, sites were located in commercial fields near Bancroft, Cortland, Elba, and at the UNL South Central Agriculture Lab (SCAL) near Clay Center, Nebraska. In 2012, sites were located in commercial fields near David City, Lexington, O'Neill, and Platte Center, NE. The previous crop was corn at all locations. Two soybean cultivars were planted in 2011 and one cultivar in 2012 (Table 1). Soybean seeds were planted at a population of 371,287 seeds/ha in 2011 and 346,535 seeds/ha in 2012. All plots were four rows wide planted on $76.2 \mathrm{~cm}$ centers, and 6.1-7.6 m long. Plots were arranged in a randomized complete block design with four replications per treatment.

Treatments were applied at the R3 growth stage and are listed in Table 2. A non-treated control was included in each location. All treatments were applied with a $\mathrm{CO}_{2}$-pressurized backpack sprayer with a $3.1 \mathrm{~m}$ wide spray boom with six Teejet XR 11002 nozzles on $50.8 \mathrm{~cm}$ spacing, pressurized to $275.8 \mathrm{kPa}$ to deliver 140.5 liter/ha of spray volume.

Foliar disease was assessed approximately 24 to 48 days after treatment applications. Septoria brown spot was the only fungal foliar disease observed at these locations. Disease severity was rated as the total percentage of canopy affected. There was no insect damage observed at any of the locations in 2011. In 2012, insect damage was assessed 14 to 24 days after treatment applications and again later on in the growing season. Plots were harvested with a small plot combine, and grain yields were standardized to $13 \%$ seed moisture. Data were analyzed in SAS using previously explained methods.

\section{EFFECT OF FUNGICIDE AND INSECTICIDE ON DISEASE SEVERITY AND YIELD}

Illinois. Treatment effect was significant in 2009 (Table 3). The non-treated control produced the lowest yield $(3,820 \mathrm{~kg} / \mathrm{ha})$ and fungicide + insecticide treatments had the highest yield, which was $269 \mathrm{~kg} / \mathrm{ha}$ more than the control. Fungicide alone increased yield by $121 \mathrm{~kg} / \mathrm{ha}$ compared to the control. Treatments of QoI and DMI fungicides yielded more than the QoI fungicide treatment alone (Table 4). In 2010, treatment did not significantly impact yield $(P=0.21)$. Cercospora leaf blight $(C$. kikuchii $[\mathrm{T}$. Matsumoto \& Tomoy] M.W. Gardner), Septoria brown spot, and frogeye leaf spot were common at the experimental sites, however the average severity for each disease was $<5 \%$ in the non-treated control (data not shown). Aphid population was below the threshold level (250 per plant) in all locations and years.

Indiana. Treatment effect was significant in $2010(P=0.04)$ only. Mean yield across treatments in 2010 ranged from 3,403 to $3,524 \mathrm{~kg} / \mathrm{ha}$ (Table 3). Fungicide and fungicide + insecticide treatments produced similar yields but yielded more than the nontreated control. Foliar disease levels were extremely low in all trials conducted across all locations and years. Septoria brown spot was observed most frequently, but at very low levels (data not shown). Frogeye leaf spot was observed at trace levels, primarily in northern Indiana trials. Insect pressure also was low. No trials met the soybean aphid threshold for insecticide applications in any year.

Iowa. Treatment significantly affected yield in four of six years (Table 3). In those four years, yield in the non-treated control was lower compared to the other treatments, except in 2013 (Table 3). 
In 2013, only fungicide + insecticide treatment was different from the control. Effect of fungicide class on yield was not significant in Iowa except in 2008 (Table 4). In 2008, treatments of QoI fungicides yielded more than the DMI + QoI and non-treated control. Disease levels were very low in all the locations and years. Septoria brown spot was frequently observed in all locations but at very low levels (data not shown). No insects, including soybean aphid, reached threshold levels.

Nebraska. Fungicide + insecticide treatments significantly increased yield by $222 \mathrm{~kg} / \mathrm{ha}$ compared to the non-treated control in 2011. Treatment did not increase yield in 2012 and fungicide class had no effect on soybean yield in either year. Septoria brown spot was reduced in fungicide and fungicide + insecticide treated plots for both years compared to the other treatments (Table 5). In 2012, QoI fungicides and DMI + QoI fungicides reduced Septoria brown spot compared to DMI fungicides and non-treated control. There was no measurable bean leaf beetle or soybean aphid feeding observed at these locations.

Economic analysis. Over the duration of these experiments, the six-year average soybean price was $\$ 0.42 / \mathrm{kg}$; therefore, this price was used to explore the economic impact of the treatments. For the fungicide only treatments, the average change in revenue was $\$ 35.60 /$ ha. The revenue changes under the fungicide only treatments ranged from $-\$ 8.60 /$ ha in Indiana in 2011 to $\$ 125.80$

\begin{tabular}{|c|c|c|c|c|c|c|c|}
\hline \multirow[b]{3}{*}{ State } & \multicolumn{7}{|c|}{$\begin{array}{l}\text { TABLE } 3 \\
\text { Least square means of soybean yield in Illinois, Indiana, lowa, and Nebraska from } 2008 \text { to } 2014 \text { following } \\
\text { application of fungicides and insecticides in a study designed to examine the effect of } \\
\text { foliar fungicide and insecticide application on soybean yield. }\end{array}$} \\
\hline & \multirow[b]{2}{*}{ Year } & \multirow[b]{2}{*}{ Locv } & \multicolumn{5}{|c|}{ Treatment category } \\
\hline & & & $F^{w}$ & $\mathbf{F}+\mathbf{I}^{\mathbf{x}}$ & I & NTCy & $P>F$ \\
\hline Illinois & 2009 & 6 & $3,941 \mathrm{~b}^{\mathrm{z}}$ & $4,089 \mathrm{a}$ & $4,028 \mathrm{ab}$ & $3,820 \mathrm{c}$ & $<0.01$ \\
\hline \multirow{3}{*}{ Indiana } & 2010 & 3 & $3,511 \mathrm{a}$ & $3,524 \mathrm{a}$ & - & $3,403 \mathrm{~b}$ & 0.04 \\
\hline & 2011 & 4 & 2,596 & 2,784 & - & 2,616 & 0.30 \\
\hline & 2012 & 5 & 3,443 & 3,504 & - & 3,376 & 0.17 \\
\hline \multirow[t]{3}{*}{ Iowa } & 2008 & 5 & $3,598 \mathrm{~b}$ & $4,170 \mathrm{a}$ & $3,988 \mathrm{a}$ & $3,302 \mathrm{c}$ & $<0.01$ \\
\hline & 2009 & 5 & $4,109 \mathrm{bc}$ & $4,250 \mathrm{a}$ & $4,190 \mathrm{ab}$ & $4,042 \mathrm{c}$ & 0.07 \\
\hline & 2011 & 5 & $4,022 \mathrm{a}$ & $4,122 \mathrm{a}$ & $4,069 \mathrm{a}$ & $3,847 \mathrm{~b}$ & $<0.01$ \\
\hline Nebraska & 2012 & 4 & 2,912 & 2,838 & 2,818 & 2,851 & 0.60 \\
\hline
\end{tabular}

$\mathrm{v}$ Treatments were applied in two to seven sites in each state and year. The number in location (loc) column indicates number of sites tested for that year and state.

${ }^{\mathrm{w}} \mathrm{F}=$ Fungicide

${ }^{\mathrm{x}} \mathrm{I}=$ Insecticide

${ }^{\mathrm{y}} \mathrm{NTC}=$ Non-treated control

${ }^{\mathrm{z}}$ Each number is the average of two to seven test locations and each location tested two to12 products with three to six replications and one to four cultivars. Means were separated by Fisher's protected least significant difference. Means followed by the same letter within a row do not differ significantly at $P=0.10$.

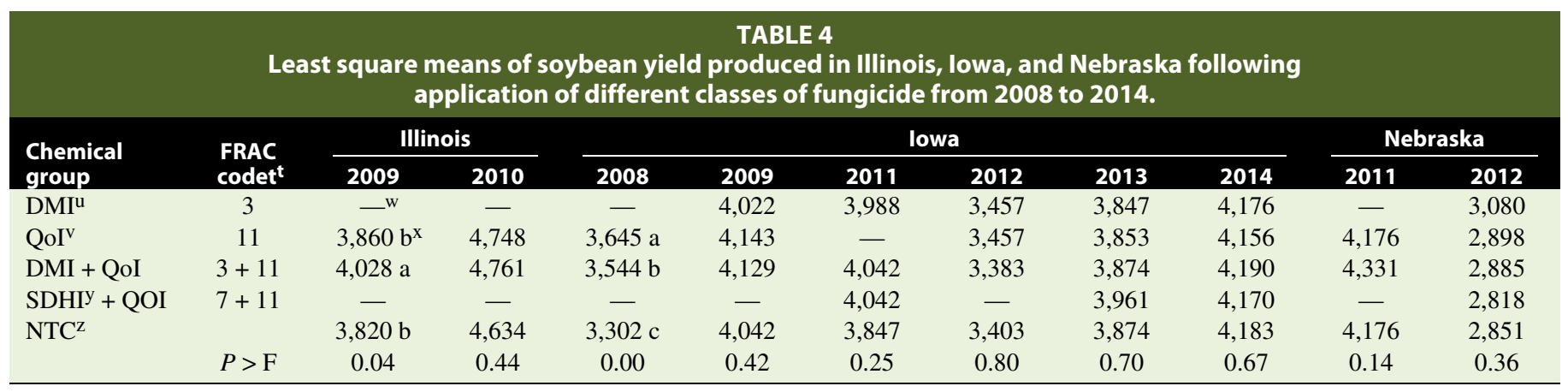

${ }^{\mathrm{t}} \mathrm{FRAC}=$ Fungicide Resistance Action Committee. The FRAC code list can be obtained online at http://www.frac.info

${ }^{\mathrm{u}} \mathrm{DMI}=$ Demethylation inhibiting

${ }^{\mathrm{v}} \mathrm{QoI}=$ quinone outside inhibiting

w - indicates that the fungicide chemical group was not tested in this state in the year indicated.

${ }^{x}$ Each number is the average of two to seven test locations and each location tested two to 12 products with three to six replications and one to four cultivars. Means were separated by Fisher's protected least significant difference. Means followed by the same letter within a column do not differ significantly at $P=0.10$.

y SDHI $=$ Succinate dehydrogenase inhibiting

${ }^{\mathrm{z}} \mathrm{NTC}=$ Non-treated control 
per ha in Iowa in 2008. For the insecticide only treatments, the average revenue shift was $\$ 55.90$ per hectare. The range of returns under the insecticide only treatments varied from $-\$ 14.30$ /ha in Iowa in 2014 and Nebraska in 2012 to \$291.60/ha in Iowa in 2008. Fungicide plus insecticide treatments increased the average return to $\$ 79.00 /$ ha, with only Nebraska in 2012 showing a negative revenue impact from the treatment. The largest revenue boost occurred in Iowa in 2008 with $\$ 368.80 /$ ha.

For the chemical classes, the average gain in soybean revenues varied from $\$ 20.20 /$ ha for the DMI fungicides to $\$ 40.60 /$ ha for the combination of DMI and QoI classes. However, each set of treatments had locations that experienced negative economic impacts. For the DMI fungicides, the revenue shifts ranged from $-\$ 11.40$ /ha in 2013 in Iowa to $\$ 97.20 /$ ha in 2012 in Nebraska. For the QoI fungicides, the range was $-\$ 11.40 /$ ha for Iowa in 2014 to $\$ 145.80$ /ha for Iowa in 2008. For the combination of DMI + QoI classes, the range was $-\$ 8.60 /$ ha for Iowa in 2012 to $\$ 102.90 /$ ha in 2008 in Iowa. Finally, for the SDHI + QoI classes, the revenue range was $-\$ 14.30 /$ ha for Nebraska in 2012 to $\$ 82.90 /$ ha for Iowa in 2011.

These results are based on specific values for soybean price. In order to account for situation-specific variability in prices and chemical and application costs, a calculator has been developed to allow individuals to enter their own price/cost information to estimate economic return using the yield data from this study. The calculator can be accessed at http://fungicide-calc.bitbyteyum. com. For example, using a soybean price of $\$ 0.42 / \mathrm{kg}$ to match the analysis above and assuming chemical and application costs of $\$ 61.90 / \mathrm{ha}$, the calculator shows that only $14 \%$ of the fungicide only treatments had economic returns that exceeded chemical and application costs, whereas $39 \%$ of the insecticide only and $45 \%$ of the combined fungicide and insecticide treatments had economic returns above \$61.90/ha.

\section{CONCLUSIONS AND CONSIDERATIONS FOR PEST MANAGEMENT IN SOYBEAN}

Our analysis of data collected over multiple years and locations indicates that fungicide and insecticide applications can increase soybean yield in the absence of disease, which may be due, in part, to physiological changes that can sometimes occur in the plant (Mahoney et al. 2015), and insecticide benefits (Henry et al. 2011). However these applications were profitable less than $50 \%$ of the time, and solo fungicide applications were profitable only $14 \%$ of the time, based on average soybean market prices and application costs.

Previous research on the impact of a fungicide and/or insectcide application on soybean yield also has been inconsistent. Several studies have demonstrated no significant increase in soybean yield with fungicide and/or insecticide applications (Hershman et al. 2004; Nelson et al. 2016; Swoboda and Pederson 2009). However, trials including fungicide + insecticide applications occasionally result in yield increases (Dorrance et al. 2010; Hershman et al. 2004). In these instances, yield increases were attributed to high levels of soybean foliar disease and/or aphids within the trials. We observed a yield increase from foliar fungicide + insecticide application nearly $50 \%$ of the time, which was profitable $45 \%$ and $39 \%$ of the time, respectively. However, foliar disease and insect levels were very low throughout the experimental locations in all years, even across a range of environments and years. Weather conditions varied widely across the years and locations (www.mesonet.agron.iastate.edu), and yet foliar diseases were rarely noted, except in Nebraska in 2011. Of the two foliar diseases of primary concern in the North Central region, Septoria brown spot is the most common disease, but is typically confined to the lower canopy and rarely causes yield loss. This disease has shown to only be yield-limiting when it reaches the upper canopy in the early reproductive stages (Cruz et al. 2010), which did not happen in the trial locations in any year. Frogeye leaf spot can be more yield limiting, but is more of an annual threat in the mid-South and southern United States. (Wrather et al. 2009), and was rarely detected over the years and locations of the study. Based on these observations over a six-year period, it may be possible that farmers in the mid-North Central region rarely need fungicide applications to manage foliar diseases. Scouting for foliar diseases prior to R3 can help farmers determine if diseases are present and at concerning levels, which could help them decide if foliar fungicides are warranted (Swoboda and Pedersen 2009).

Likewise, insect levels never reached threshold levels in the trials, and insecticides may not be needed. Insecticide applications were almost as profitable as fungicide + insecticide applications, so farmers could reduce input costs by only applying an insecticide if scouting reports indicate an insect problem, but low foliar disease levels.

While we have focused primarily on the economic costs/ benefits of application, but it is important to also address that widespread fungicide and insecticide applications may eliminate beneficial insects or fungi (Nelson et al. 2016; Wise and Mueller 2011) and increase the risk of secondary problems, such as the resurgence of target pests, and pesticide poisoning to humans, wildlife, honeybees, livestock etc. (Pimentel 1993). Widespread fungicide use also increases the risk of fungicide resistance development. Currently, several soybean pathogens have been reported as less sensitive or resistant to QoI fungicides in the North Central region, including $C$. sojina, in Illinois and Tennessee (Zhang et al. 2012) and Mississippi (Standish et al. 2015). The causal fungus of Cercospora leaf blight (C. kikuchii)

\begin{tabular}{|c|c|c|}
\hline \multicolumn{3}{|c|}{$\begin{array}{l}\text { TABLE } 5 \\
\text { Least square means of brown spot (Septoria glycines) } \\
\text { severity recorded in Nebraska following application } \\
\text { of different classes of fungicide and insecticide from } \\
2011 \text { and } 2012 \text {. }\end{array}$} \\
\hline \multirow[b]{2}{*}{ Treatment category } & \multicolumn{2}{|c|}{ Brown spot severity } \\
\hline & 2011 & 2012 \\
\hline $\begin{array}{l}\text { Fungicide alone } \\
\text { Fungicide }+ \text { Insecticide } \\
\text { Insecticide alone } \\
\text { Non-treated Control } \\
P>\mathrm{F}\end{array}$ & $\begin{array}{l}35.7 \mathrm{~b}^{\mathrm{V}} \\
36.3 \mathrm{~b} \\
39.9 \mathrm{a} \\
39.0 \mathrm{a} \\
0.03\end{array}$ & $\begin{array}{l}3.7 \mathrm{~b} \\
3.9 \mathrm{~b} \\
5.3 \mathrm{a} \\
6.2 \mathrm{a} \\
<0.01\end{array}$ \\
\hline \multicolumn{3}{|l|}{ Chemical group } \\
\hline $\begin{array}{l}\mathrm{DMI}^{\mathrm{w}} \\
\text { QoI' }^{\mathrm{y}} \\
\mathrm{DMI}+\text { QoI } \\
\mathrm{SDHI}^{\mathrm{z}}+\text { QoI } \\
\text { Non-treated Control } \\
P>\mathrm{F}\end{array}$ & $\begin{array}{l}-\mathrm{x} \\
35.7 \\
35.7 \\
- \\
39.0 \\
0.36\end{array}$ & $\begin{array}{l}5.0 \mathrm{ab} \\
3.3 \mathrm{c} \\
3.2 \mathrm{c} \\
4.2 \mathrm{bc} \\
6.2 \mathrm{a} \\
<0.001\end{array}$ \\
\hline $\begin{array}{l}\text { veans were separated } \\
\text { difference. Means follo } \\
\text { differ significantly at } P \\
{ }^{\mathrm{w}} \mathrm{DMI}=\text { Demethylation } \\
\mathrm{x} \text { — indicates that the fur } \\
\text { year indicated. } \\
\text { y QoI = quinone outside } \\
{ }^{\mathrm{z}} \mathrm{SDHI}=\text { Succinate dehy }\end{array}$ & $\begin{array}{l}\text { rotected } \\
\text { ame lett } \\
\text { ical grou } \\
\text { lhibiting }\end{array}$ & $\begin{array}{l}\text { cant } \\
\text { olumn do no } \\
\text { ested in the }\end{array}$ \\
\hline
\end{tabular}


has been reported to be resistant to QoI fungicides (Price et al. 2015) indicating that resistance issues are more widespread across soybean production areas in the United States (Price et al. 2015; Standish 2015; Zeng et al. 2015).

Because of this, we recommend using an integrated management approach to manage soybean foliar diseases, including planting cultivars with resistance to frogeye leaf spot, implementting crop rotation to reduce soybean residue, and scouting soybeans prior to R3 to determine if foliar diseases and insects are at levels that warrant applications. If fungicides are needed, we advocate using products with mixed modes of action, such as a $\mathrm{DMI}+$ QoI, or an SDHI + QoI, and not solo QoI products, to reduce the speed at which fungicide resistance will be detected in the North Central region.

\section{ACKNOWLEDGMENTS}

This research was partially funded with soybean checkoff through the Illinois Soybean Association, the Indiana Soybean Alliance, the Iowa Soybean Association, and the Nebraska Soybean Board. We would also like to thank N. Anderson, D. Biehle, J. Boyer, J. Leuck, D. Nowaskie, J. Ravellette, and P. Walker in Indiana, and S. Wiggs from Iowa State University for trial assistance.

\section{LITERATURE CITED}

Bartlett, D. W., Clough, J. M., Godwin, J. R., Hall, A. A., Hamer, M., and Parr-Dobrzanski, B. 2002. The strobilurin fungicides. Pest. Manag. Sci. 58:649-662.

Cruz, C. D., Mills, D., Paul, P. A., and Dorrance, A. E. 2010. Impact of brown spot caused by Septoria glycines on soybean in Ohio. Plant Dis. 94:820826.

Dorrance, A. E., Cruz, C., Mills, D., Bender, R., Koenig, M., LaBarge, G., Leeds, R., Mangione, D., McCluer, G., Ruhl, S., Siegrist, H., Sundermeier, A., Sonnenberg, D., Yost, J., Watters, H., Wilson, G., and Hammond, R. B. 2010. Effects of foliar fungicide and insecticide applications on soybean in Ohio. Plant Health Prog. doi:10.1094/PHP2010-0122-01RS.

FRAC. 2016. Fungicide Resistance Action Committee Code List 2016. Fungicides sorted by mode of action. http://www.frac.info/publications.

Fehr, W. R., Caviness, C. E., Burmood, D. T., and Pennington, J. S. 1971. Stage of development descriptions for soybeans, Glycine max (L.) Merrill. Crop Sci. 11:929-931.

Hanna, S., Conley S., Santini, J., and Shaner, G. 2007. Soybean production systems: Managing fungicide applications in soybean. Ext. Bull. SPS103-W. Purdue Univ., West Lafayette, IN.

Hartman, G. L. 2015. Brown spot. Pages 36-37 in: Compendium of Soybean Diseases and Pests. G. L. Hartman, J. C. Rupe, E. F. Sikora, L. L. Domier, J. A. Davis, and K. L. Steffey, eds. American Phytopathological Society, St. Paul, MN.

Hartman, G. L., Domier, L. L., Wax, L. M., Helm, C. G., Onstad, D. W., Shaw, J. T., Solter, L. F., Voegtlin, D. J., D'Arcy, C. J., Gray, M. E., Steffey, K. L., Isard, S. A., and Orwick, P. L. 2001. Occurrence and distribution of Aphis glycines on soybeans in Illinois in 2000 and its potential control. Plant Health Prog. doi:10.1094/PHP-2001-0205-01-HN.
Henry, R. S., Johnson, W. G., and Wise, K. A. 2011. The impact of a fungicide and an insecticide on soybean growth, yield, and profitability. Crop Prot. 30:1629-1634.

Hershman, D., Johnson, D., and Herbek, J. 2004. Quadris and Warrior use on soybean: A means of capturing additional yield? Kentucky Pest Newsl., Univ. of Kentucky, Lexington. http://www.uky.edu/Ag/kpn/kpn_04/ pn040209.htm.

Mahoney, K. J., Vyn, R. J., and Gillard, C. L. 2015. The effect of pyraclostrobin on soybean plant health, yield, and profitability in Ontario. Can. J. Plant Sci. 95:285-292.

Mueller D. S., Wise, K. A., Dufault, N. S., Bradley, C. A., and Chilvers, M. A., eds. 2013. Fungicides for Field Crops. American Phytopathological Society Press, St. Paul, MN.

Nelson, K. A., Tindall, K. V., Wrather, J. A., Stevens, W. E., and Dudenhoeffer, C. J. 2016. Value of an insecticide added to a fungicide for soybean during drought. Crop Forage and Turfgrass Manag. doi: $10.2134 / \mathrm{cftm} 2015.0195$

O'Neal, M. 2005. Insecticide use for soybean aphid control up again in 2005. In: Integrated Crop Management, Iowa State University. 10 October 2005. http://www.ipm.iastate.edu/ipm/icm/2005/10-10/aphids.html.

Pimentel, D., McLaughlin, L., Zepp, A., Lakitan, B., Kraus, T., Kleinman, P., Vancini, F., Roach, W. J., Graap, E., Keeton, W. S., and Selig, G. 1993. Environmental and economic effects of reducing pesticide use in agriculture. Agric. Ecosyst. Environ. 46:273-288.

Price, P. P., III, Purvis, M. A., Cai, G., Padgett, G. B., Robertson, C. L., Schneider, R. W., and Albu, S. 2015. Fungicide resistance in Cercospora kikuchii, a soybean pathogen. Plant Dis. 99:1596-1603.

Ragsdale, D. W., Landis, D. A., Brodeur, J., Heimpel, G. E., and Desneux, N. 2011. Ecology and management of the soybean aphid in North America. Ann. Rev. Ent. 56:375-399.

Standish, J. R., Tomaso-Peterson, M., Allen, T. W., Sabanadzovic, S., and Aboughanem-Sabanadzovic, N. 2015. Occurrence of QoI fungicide resistance in Cercospora sojina from Mississippi soybean. Plant Dis. 99:1347-1352.

Swoboda, C., and Pedersen, P. 2009. Effect of fungicide on soybean growth and yield. Agron. J. 101:352-356.

Wise K. A. 2016. Diseases of soybeans: Fungicide efficacy for control of soybean foliar diseases. Purdue Ext. Bull. SPS-103-W. BP-161-W.

Wise, K., and Mueller, D. 2011. Are fungicides no longer just for fungi? An analysis of foliar fungicide use in corn. APSnet Feature Article. doi:10.1094/APSnetFeature-2011-0531.

USDA-NASS. 2015. Quick Stats 2.0. http://www.nass.usda.gov. Washington, DC.

Wise, K. A., and Newman, M. E. 2015. Frogeye leaf spot. Pages 43-45 in: Compendium of Soybean Diseases and Pests. G. L. Hartman, J. C. Rupe, E. F. Sikora, L. L. Domier, J. A. Davis, and K. L. Steffey, eds. American Phytopathological Society, St. Paul, MN.

Wrather, J. A., and Koenning, S. R. 2009. Effects of diseases on soybean yields in the United States 1996 to 2007. Plant Health Prog. doi:10.1094/PHP-2009-0401-01-RS.

Zeng, F., Arnao, E., Zhang, G., Olaya, G., Wullschleger, J., Sierotzki, H., Ming, R., Bluhm, B. H., Bond, J. P., Fakhoury, A. M., and Bradley, C. A. 2015. Characterization of quinone outside inhibitor fungicide resistance in Cercospora sojina and development of diagnostic tools for its identification. Plant Dis. 99:544-550.

Zhang, G. R., Newman, M. A., and Bradley, C. A. 2012. First report of the soybean frogeye leaf spot fungus (Cercospora sojina) resistant to quinone outside inhibitor fungicides in North America. Plant Dis. 96:767. 